Leaving out of account frictional generation of heat (in other words, the effect which varies as the square of the current), let $\sigma d \theta$ be the heat generated in unit time by unit current in a uniform copper bar, in passing from a section where the temperature is $\theta+d \theta$ to one where it is $\theta$ (see Thomson's "Papers," vol. i. p. 246). Let $x$ be distance along the bar in the direction of the current, and $c$ the thermal capacity of unit length of the bar. The heat generated in a short length $\delta x$ is $-\sigma \frac{d \theta}{d x} \delta x$, and the consequent rise of temperature in this portion is $-\frac{\sigma}{c} \frac{d \theta}{d x}$. This is in unit time. Hence, putting $t$ for time, and $z^{\prime}$ for $\frac{\sigma}{c}$, we have-

$$
\frac{d \theta}{d \ell}=-v \frac{d \theta}{d x}
$$

If the limits of temperature are not very far apart, it is known that $\sigma$ and $c$ are sensibly independent of $\theta$; hence $v$ may be treated as a constant. The integral of the above equation is then-

$$
\theta=F(x-v t),
$$

where $F$ is a functional symbol such that $\theta=F(x)$ expresses the original distribution of temperature. The interpretation is that the original "temperature curve" travels forward with velocity $v$ without flattening or any other change of form.

Belfast, May I4

J. D. Everett

\section{Scientific Nomenclature}

Some time ago Mr. "John O'Toole," in the columns of NATURE, waged war against that hideous monstrosity Potential Energy, and he very aptly summarised his case against this term by saying that it involves, by the very signification of words, "a double remotion from actuality."

A few months ago it occurred to me that to express what is intended by the potential energy of any system the term Static Energy is not only logically unobjectionable but specially fit for the purpose. Thus, if a string or a membrane is stretched, a wire bent and twisted, or, generally, a body strained in any manner, the work which it can do against resistance in returning from its state of strain to its unstrained condition is the Static Energy of the system in the strained condition. The work which a moving system can do in virtue solely of its motion is, of course, its Kinetic Energy.

Thus we have simply Static Energy and Kinetic Energy, and these terms have the further advantage of harmonising with the ordinary subdivisions of dynamics.

I may add that the term Static Energy has received the approval of all the mathematical physicists to whom I have submitted it.

R.I.E. College, Cooper's Hill, May I9 EORGE M. MiNCHIN

\section{Pendulum Oscillation}

THE oscillations of a long pendulum are observed to describe an ellipse the axis of which tends to set itself at right-angles to the plane in which the pendulum was started. An explanation of the above phenomenon would much oblige. M. H. MAW

Walk House, Barrow-on-Humber, Hull, May 18

\section{What is Histioderma?}

Histioderma hibernica was described by Dr. Kinahan in 1858 as an annelid, and most writers who have since mentioned it have also regarded it as such. Dr. Haughton notices and figures it in his "Manual of Geology," Sir R. I. Murchison places it amongst annelids in his "Siluria," as also Dr. Bigsby in hi "Thesaurus Siluricus." Writing from memory only, I think a description and figure will be found in W. H. Baily's useful compendium of Palæozoic British fossils, published a few years ago. The fossil is mentioned with more or less detail by numerous writers on Cambrian strata.

The above references will perhaps answer the letter signed "S.," but there still remains the question, What is Histioderma? It is apparently a fossil impression in the rocks of Bray Head, Wicklow, Ireland. Only one species and only one locality is, I believe, known. It seems to me very doubtful what kind of animal made the impression-whether an annelid, or otherwise. I am inclined to doubt if the rocks are Lower Cambrian, as geologists generally suppose, because the evidence seems to indicate that the Bray Head rocks had become hardened and raised into land before the oldest Lower Cambrians of Wales and England were deposited. I would therefore pass on the question and ask, What is Histioderma?

4, Cowper Road, Acton, London, W.

A. RAMSAy

IN answer to the above question in your issue of May 20 (p. 53), I refer your correspondent to the Proceedings of the Geological Society of Dublin, where he will find (Natural History Reviez, vol, v., Proceedings of Society, p. I50) the original description of Histioderma by Prof. Kinahan. According to its author, Histioderma is the tube of a cephalo-branchiate annelid.

Leipzig, May 23

J. VICTOR CARUS

\section{Black Skin}

IN a letter lately received from Mr. Flinders Petrie, who is now in Egypt, are some remarks on "Black Skin," which I think very interesting, and perhaps the readers of NATURE may think them so too, so I send the paragraph to you.
Belvedere, Kent, May 24
F. C. J. Spurrell.

"In considering the use of a naturally or artificially black skin, we should not look so much to the requirements of the surface, which is constructed to bear variations, and has the means of cooling and maintaining a proper temperature within itself, but rather we should consider the far more delicate tissues beneath. We all know how translucent flesh is to strong light, and it can hardly be doubted that the rays of a tropical sun would light up a white man's inside considerably; whereas black skin would stop out the solar energy of light, heat, and chemical rays effectually. Skin heat is of no importance, as perspiration can always keep that down. May not the oiling of the skin in hot countries be partly to make it reflective, so that it should absorb less heat? And may not the regard white races have for clothing be partly for the purpose of keeping the insides of their bodies sufficiently in the dark?"

\section{Male Animals and their Progeny}

CAN any of your correspondents inform me whether any of the male wild animals in foreign countries show any love for, or recognition of, their progeny? In this country amongst the domestic animals it does not seem to exist, save in the case of the gander, who carefully guards the goose while sitting, and attends to the goslings when hatched; but the cock pays no attention to the hen while sitting nor when with chickens, nor does the dog, the bull, the horse, nor the boar evince any sign of parental feeling under circumstances favourable to its development.

One peculiarity of geese is, I think, worthy of notice, for it is not possessed by ducks or fowls, who also live in flocks. If when goslings are hatched, they are permitted to run with a goose in company with the other geese of the flock, all chances of any eggs being laid by the other geese who have no goslings are over.

P.

\section{Birds and Mirrors}

For six days I have been for two or three hours in the club reading-room, where t'ere is a large mirror. During all this time a cock and hen sparrow have been flirting with and bowing to their images in the glass with evident pleasurerushing along the mantel-shelf, flying to the top of the frame, or resting for a time, always apparently happy in contemplation, never showing disappointment. F. C. CoNSTABLE

Sind Club, Karáchi, May 2

\section{SURGEON-MAFOR T. R. LEWIS}

$\mathrm{D}^{\mathrm{R}}$ R. TIMOTHY LEWIS, Surgeon-Major Army Medical Staff and Assistant Professor of Pathology in the Netley Army Medical College, whose death, which took place on May 7, we announced last week, was a native of South Wales, and received his medical education at University College, London, and graduated as M.B. at Burlington Gardens. He was selected about twenty 